\title{
João Mendes de Almeida Jr. - Aspectos de uma grande vida.
}

\author{
Alfredo Buzaid
}

Livre docente de Direito Judiciário Civil na Faculdade de Direito da Universidade de São Paulo

\section{I - A família Mendes de Almeida.}

1 - Joño Mendes de Almeida nasceu a 22 de maio de 1831 na vila de Caxias. Contava apenas oito anos de idade, quando irrompeu uma sublevação na Província. A praça fôra sitiada pelos rebeldes. Os habitantes porfiam na defesa, fabricando cartuchos. Travam-se combates violentos e encarniçados, deixando mortos e feridos no campo de batalha. Porém a cidade não logrou resistir por muito tempo; capitulou. Começa a evacuação dos civis, através do rio Itapicurú, localizando-se os fugitivos na povoação, denominada Coroatá. Dominada a rebelião, regressa a família Mendes de Almeida. A situação era dolorosa. Perdera a maior parte dos cabedais. A 20 de setembro de 1840 morre Fernando Mendes de Almeida, deixando três órfãos e o filho mais velho, CÂndibo Mendes de Almeida, já formado em direito. (2)

(1) Conferência proferida na Faculdade de Direito de S. Paulo, no dia 29 de Outubro de 1956, por ocasião das comemorações do primeiro centenário de JoÃo Mendes de Almeida Júnior.

(2) Cf. JoÃo Mendes de AlmeIdA, Algumas notas genealógicas, S. Paulo, 1886, p. 459 e seg. 
2 - Apesar das dificuldades financeiras, João Mendes. DE Almeida fôra enviado para a Capital e internado no Colégio Nossa Senhora dos Remédios, onde permaneceu até 1846. Aí fêz os preparatórios; seguiu depois para Olinda, onde cursou a Faculdade de Direito. Em 1852 transferiu-se para São Paulo, a fim de concluir o curso nesta Faculdade, quando é obstado por um aviso do Ministro. do Império, Francisco Gonçalves Martins, expedido ao Diretor, ordenando-lhe que não lhe permitisse prestar $o$ ato e tomar o grau, antes de se defender da acusação de tentativa de morte contra o Prof. Pedro Autran da Mata e Albuquerque.

Joâo Mendes de Almeida regressa para Olinda. Tratando-se de crime inafiançável, não podia livrar-se sôlto. Solicitou ao Chefe de Polícia guia para recolher-se ao Estado Maior e da decisão de pronúncia interpôs recurso, que tocou ao magistrado José Tomás Nabuco de Araújo. O provimento do recurso reconheceu a inocência do jovem acadêmico, que pôde voltar para São Paulo. Concluído o curso, foi nomeado pouco depois juiz municipal em França do Imperador e juiz de direito da Capital. O Ministro da Justiça era então José Tomás Nabuco de Araújo. (3)

3 - Estes dois fatos marcam indelèvelmente a existência de João Mendes de Almeida. Aos oito anos assiste aos horrores da guerra fratricida. Mas o quadro, longe de lhe entibiar a alma, infunde nela o sentimento da coragem, revigora o ânimo de luta e acrisola o amor da Pátria. Na. mocidade, pouco antes de sua formatura, conheceu o travo da injustiça. Mas a falsa acusação, que ordinàriamente abate os covardes, levantou o jovem, dotado de ânimo forte. O indiciado não foge; defende-se. Sendo inocente, é absolvido. Já agora pode começar a trajetória de sua vida como juiz, advogado, jornalista, político e escritor.

(3) JoÃo Mendes de Almeida, Algumas notas genealógicas, p. 462; Francisco Morato, Discursos e conferências, S. Paulo, 1952. p. 52 . 
Homem independente, dedicou-se ao serviço da Nação. Eleito deputado, integra comissões parlamentares, que opinam sôbre o projeto de interpretação do Ato Adicional, da Lei do Ventre Livre e da reforma eleitoral. Joaqurm NABuco, fazendo-lhe o elogio na sessão do Instituto Histórico de 15 de dezembro de 1898, assinalou: "Ele é quase um rebelde, faz vida política à parte, tem a sua esfera de influência exclusiva, trancada, hostil a qualquer intervenção êle não tem vida própria, não pode fechar a porta, não tem horas de comida, não tem direito ao sono". (4)

4 - Católico convicto e fervoroso, direi mesmo ultramontano, adota o lema manet immota fides. JoAQUIM NADuco dizia ainda, referindo-se à fé religiosa de João Mendes de Almeida: "O homem público que prefere resolutamente, como êle, acima de tudo o interêsse da Igreja, tem que se inspirar só na politica do Evangelho. Em substância, o que êle era, era sòmente um católico; tudo o mais era accessório, corolários políticos que tirava de sua premissa religiosa, meios de alcançar o seu único desideratum. É assim que se pode medir a verdadeira distância a que êle se acha das idéias que hoje se respiram. Êle foi um dêsses políticos que trabalharam, não por uma época ou por um país, mas pela eternidade e pelo homem." (5).

5 -- João Mendes de Almeida casou-se com Da. Ana Rita Fortes Leite Lobo no dia 17 de fevereiro de 1855. Do consórcio nasceram três filhos, dos quais o primogênito foi JoÃo Mendes de Almeida Júnior. Em 1886 João Mendes de Almeida publicou em São Paulo uma obra intitulada -"Algumas notas genealógicas", com o subtítulo - "Livro de familia" A obra é dedicada aos seus filhos e contém um notável prefácio, no qual assinala que a nobreza é

(4) JoAquim Nabuco, Escritos e discursos literários, obras completas, vol. IX, p. 216.

(5) JoAquim Nabuco, op. cit. p. 217 e seg. 
antes uma qualidade do que um título; (6) convencido de que "o maior respeito aos antepassados será a constante prática das virtudes, quer na família, quer na sociedade" (7), procurou recordar a linhagem na qual entroncava a sua estirpe; e sendo católico fervoroso, concluiu as palavras preliminares, dizendo: “Êste livro é um simples canhenho da família. Se estranhos o lerem, considerem sòmente na intenção que o ditou. Quero que meus filhos amem a Deus sôbre tôdas as coisas, afim de que saibam praticar as virtudes, $e$ possam assim perpetuar na prole a legitimidade, sob tôdas as relações da vida: "in filiis suis agnoscitur vir" (Eclesiastico, XI, 30). (8)

6 - João Mendes de Almeida Júnior descende dessa linhagem. As qualidades de seu pai vão refletir-se nêle, moldando-lhe o caráter, infundindo-lhe a crença religiosa e aprimorando-lhe os dotes da inteligência e do talento. Ele herdara de seu pai uma tradição de honra e de espiritualidade, a bondade do coração e o ânimo combativo. Refere-nos Francisco Morato que o pai aconselhava o filho, "quando investido no cargo de lente, a'ser invariàvèlmente bom para com os alunos." (9) Atento a êste conselho paternal, aprovava-os sistemàticamente. "Quando o aluno não sabia o que era perguntado", ensinava-lhe e, como a reprovação era uma sentença contra os ignorante, aprovava por sistema, porque, se o examinado não tinha aprendido nas aulas, saía sabendo nos exames." (1) João Mendes DE ALMeida JÚNior não tinha apenas amor por seu pai; respeitava o seu talento, venerava as suas virtudes morais e admirava o seu ardor combativo pela fé e pela Pátria.

(6) JoÃo Mendes DE AlmeidA, Algumas notas genealógicas, p. IV.

(7) JoÃo Mendes de Almeida, op. cit. p. V.

(8) JoÃo Mendes de Almeida, op. cit. p. VI.

(9) Francisco Morato, Discursos e conferências, p. 53.

(10) Francisco Morato, op. cit. p. 51. 
Quando amigos e admiradores lhe exaltavam as qualidades intelectuais, considerando-as superiores às do pai, o filho se contrariava, censurando o exagero, não por falta modéstia senão pelo orgulho da origem.

\section{II - Duas etapas na vida de João Mendes Júnior.}

7 - Há na vida de JoÃo MENdes JúnIor duas fases marcantes, nitidamente separadas pela morte de seu pai. A primeira transcorre alegre, impetuosa, saudável e exuberante, especialmente no período em que freqüentou esta Faculdade como estudante. Traja-se com rigor e perfuma-se com essências francesas. Sempre bem humorado, participa da vida acadêmica, conta anedotas, não se esquiva às pândegas que acabam não raro em bengaladas e garrafadas. (11) Pertence a êste período a sua atividade no jornalismo. Durante algum tempo dirigiu a "Gazeta de Mogi-Mirim", tratando dos assuntos mais variados, especialmente sociológicos. Pôs o jornal a serviço da causa abolicionista. Quando começou a onda de fugas, que precedeu a lei Áurea, ocupava as funções de delegado de polícia naquela cidade Joaquim Firmino, que se recusava sistemàticamente a perseguir os escravos. Indignaram-se os fazendeiros e formularam ameaças. Joaquim Firmino continua inabalável. Foi então planejado o assassínio. A 11 de fevereiro de 1888 um bando de facínoras invade-lhe a casa e mata-o a golpes. Washington Prado conta que "o povo de Mogi-Mirim prestou inequívocas provas de respeito à memória de Joaquim Firmino, indo buscar-lhe o corpo, em trem especial, no próprio dia do crime. Os cativos fugidos, procedentes dos municípios vizinhos e atraídos pelo clima de liberdade, afluem em massa para a cidade.

(11) Cf. Francisco Morato, Discursos e conferências, p. 48; Peláglo Lobo, Recordações das Arcadas, p. 53. 
Joâo Mendes Júnior, à frente da "Gazeta de Mogi-Mirim", continúa impàvidamente colaborando na campanha libertária. Mas não o faz sem risco de vida. Também querem matá-lo. O povo, entretanto, está vigilante." (12) Êste episódio assinala o destemor de JoÃo Mendes Júnion em face do perigo. Se a causa era digna, o receio era uma covardia.

8 - Bem diversa foi a segunda fase, caracterizada pela circunspecção, por um certo ar de angústia, por entranhado sofrimento interior. Quando se debruça numa janela e fita algum ponto, não é para olhar o mundo exterior senão o interior, ensimesmando-se nas longas reflexões. A vida contemplativa substitui a vida ativa. O advogado militante e o jornalista intemerato da campanha abolicionista cedem o lugar ao jurista, que emite pareceres e ao homem, que aperfeiçoa dia a dia as suas virtudes morais. A vocação religiosa, que veio do berço, banhada pelos afagos maternos, já agora se escuda na convicção filosófica aristotélico-tomista. Em 1902 traduz a obra de S. João Clímaco, intitulada "Climax" ou "Escada do Céu", apondo-lhe um notável prefácio. Começa aí a manifestação pública de sua fé interior. (13)

\section{III - 0 católico e a tradução de "climax" ou "escada do céu".}

9 - O sábio, quando escreve, dá muito do seu e pouco do alheio. 0 tradutor, ao contrário, dá tudo do alheio e nada do seu. Embora estas duas afirmações sejam verdadeiras, não se pode negar que tôda tradução, especialmente de obras filosóficas ou religiosas, revela uma identidade

(12) Washington PRAdo, História de uma cidade bandeirante, 1951, Mogi-Mirim; p. 79.

(13) E curioso que, abaixo de sel nome, indica os seus títulos na seguinte ordem: "Irmão terceiro da ordem franciscana e lente catedrático da Faculdade de Direito de S. Paulo". 
espiritual entre o autor e o tradutor. É o que se sente ao ler o livro de S. Joño Clímaco, denominado "Climax" ou "Escada do Céu", pôsto em vernáculo por JoÃo Mendes JÚNioR. (14). A obra do santo data dos fins do século VI ou primórdios do século VII, discorre sôbre as virtudes que aperfeiçoam a criatura e indica o caminho que conduz à imortalidade. No prólogo, o tradutor espanhol disse: "Para tratar desta matéria, requer-se principalmente santidade e experiência das coisas espirituais, porque é isso que principalmente faz os homens sábios nesta doutrina, como disse o Profeta - Por teus mandamentos, Senhor, entendi, querendo significar que o exercício e o cumprimento dos mandamentos de Deus, é o principal mestre desta celestial filosofia." (15)

10 - A edição em idioma nacional irmanou autor e tradutor. Ambos pregaram pela pena o que realizaram pelo exemplo. $O$ tradutor compreendeu e amou o Santo, porque nêle se identificou; o autor se refletiu no tradutor, porque a vida dêste também foi banhada pelo olor da santidade. João Mendes Júnior desdenhou os bens materiais do mundo, mortificou paixões, cultivou a penitência, praticou o jejum e observou a temperança; em sua alma nunca entrou o sentimento da ira e depressa saiu a tristeza da injúria recebida; amou a vida e sempre temeu a Deus, a Quem se unia todos os dias pela oração.

11 - A Igreja grega consagra o dia 30 de março à celebração de S. João Clímaco. João Mendes Júnior nasceu no dia 30 de março. "Eu nasci", escreveu no prólogo da edição brasileira, "eu nasci no dia 30 de março de 1856; minha mãe, minha boa e santa mãe, foi a primeira pessoa de quem ouvi o nome do santo do dia do meu nascimento;

(14) São João Clímaco,. Climax ou Escada do Céu, tip. Espíndola, Siqueira \& Cia., S. Paulo, sem data; traduzida do grego para - espanhol por Fr. Luis de Granada e do espanhol para o porđuguês por João MENDES DE AlMEIDA Júnior.

(15) São João Clímaco, op. cit. prólogo, p. VI e VII. 
dois irmãos meus, Maria e Fernando, êste já chamado ao seio de Deus, nasceram nesse mesmo dia, aquela em 1858 e esta em 1860; meu pai, cuja vida foi uma escada de virtudes e cujos últimos anos foram de contínua penitência e constante oração, incitou-me a promover a construção de uma capela dedicada a S. JoÃo CLímaco, nos limites dos municípios desta Capital e de S. Bernardo, assistiu à cerimonia da bênção local, celebrada pelo Padre César de Angelis, da Companhia de Jesus e foi o primeiro signatário do respectivo auto. Ali atualmente está formado um bairro, que os moradores do lugar denominaram bairro de $S$. João Clímaco, nome que, afinal, foi consagrado nos autos oficiais do Govêrno de São Paulo. Sirva a capela de ponto de retiro espiritual; e Deus se digne abençoar êste meu esfôrço como penitência dos meus pecados." (16)

O fervor religioso de João Mendes Júnion não o ergueu apenas à contemplação mística; levou-o a construir uma Igreja, em honra do Santo, cujo nome embalara a sua me-ninice e a cuja devoção dedicara tôda a sua existência. O nascimento de três filhos, no dia consagrado à memória de S. JoÃo CLÍmaco, não era mera coincidência; havia nos desígnios da Providência o propósito de premiar aquela santa. mãe, abençoando o nascimento de seus filhos no dia do. Padroeiro de sua devoção.

12 - Sua alma está saturada de bondade, natural e es-pontânea. E esta virtude, que santifica a sua vida, se casara com a dedicação ao magistério, que foi a sua vocação irresistível. Seu filho, Joño Mendes NeTo, tira à luz em 1937 uma obra de filosofia, denominada "Elementos de lógica $e$ de psicologia". Esta obra não foi escrita pelo Mestrepor mero deleite intelectual, ou pelo desejo de especulação acadêmica. For uma dádiva do pai ao filho, quando êste se preparava para os exames de admissão à Faculdade de Direito. Organizou, compôs e escreveu os pontos do programa, aprovado pela Congregação; o filho tinha à mão

(16) São João Clímaco, op. cit. prólogo, p. XVII. 
tôda a matéria, exposta com rigor de técnica e elegância literária. Que teria influido na alma de JoÃo MENDEs Júnior para escrever os "Elementos"? A bondade do pai ou a vocação do mestre? Ou ambas? Ao que parece, não se podem distinguir estas virtudes, que compõem a sua formação espiritual. O Mestre, ensinando, era sempre um pai. $O$ pai, velando pela educação dos filhos, era sempre um mestre. (17)

IV - $O$ professor e a filosofia do direito judiciário.

13 - JoÃo Mendes JúnIOR foi um professor à maneira européia. A preocupação dos escritores do velho Mundo é a de dizer algo de novo e oferecer uma contribuição própria. Repetir o que já foi ensinado é inútil, ou pelo menos tem minguado merecimento. Não se há de exigir sempre uma investigação totalmente nova; basta muitas vêzes uma idéia, contanto que contribua para o progresso da ciência. Sob êste aspecto, ninguém excede João Mendes Júnior. A sua doutrina é indisputàvelmente original, tem rigor na disposição e perf́eita unidade do conjunto. João Mendes JúNIOR não se contentou com uma idéia; construiu um sistema.

14 - A sua contribuição original consistiu em elaborar, entre nós, uma filosofia do direito judiciário. É certo que Harscher V. Almendingen, já em 1797, aconselhava, como guia no estudo da ciência jurídica, investigar, juntamente

(17) O Prof. Reinaldo Porchat que fôra companheiro de Joäo Mendes Júnior desde os bancos acadêmicos e depois seu colega de Congregação, deu o testemunho do caráter paternal de sua vida: "JoÃo MENDES era um professor que ensinava paternalmente. E bem se vê, pela maneira e pelo meticuloso cuidado com que escreveu essas lições para ensinar o seu filho, que não the era forçado o carinho e a bondade com que ensinava aos alunos da Faculdade, considerando-os também como seus filhos." (João MENdes JúnIOR, Elementos de L6gica e de Psicologia, Saraiva \& Cia. 1937, prefácio). 
com a filosofia, a história do direito positivo. (18) No entanto, a aplicação dos princípios filosóficos à ciência do progresso só raramente ocorreu, podendo lembrar-se, se me não engano, apenas duas construções: a de Wilhelm SAUer na Alemanha e a de João Mendes Jứnıor no Brasil. Não sei de outras construções ou tentativas, feitas em outros tempos e por outros escritores.

15 - Sauer, filósofo, sociólogo e jurista, criou uma obra de sentido profundamente humano. A sua filosofia é influenciada pelo "sociológico" e sob êsse aspecto marca a evolução do século XX. Ligado à Escola Sud-Ocidental alemã, ou culturalista, a sua criação original é " a monada de valor", com que, tomando um conceito já formulado por Leibniz e Fichte, dá-lhe uma expansão inteiramente nova e marcante, com a teoria da autoridade da coisa julgada (Rechtskraft), que recorda de algum modo a concepção ficcionalista de Varhinger (19) — Não se pode filiar a concepção processual axiológica de SAUER a nenhuma corrente da processualistica. $O$ antigo professor de Koenigsberg colheu na filosofia de LeIBNiz o conceito de "monada" e em Fichte o conceito de "valor"; e fundiu-as no sincretismos da "monadologia do valor." Esta teoria das monadas do valor, que repetidamente encontrou repercussão na obra de Sauer, não é senão uma conseqüência, do ponto de vista cultural, das mais elevadas questões postas pela metafísica e um ensaio para resolvê-las, sem sair de limites rigorosamente científicos. As monadas de valor constituem a essência das coisas. Com elas tem que operar tôda

(18) HaRScher v. Almendigen Ueber den materiellen und formellen Concurs der Glaeubiger, 1797, Giessen, n. 88. João MENDES JúNIor emprestava excepcional importância aos estudos históricos. Haja vista, entre outros, os seguintes trabalhos: O processo criminal brasileiro, $3{ }^{\text {a }}$ ed. Rio, 1920, vol. I, p. II e segs.; órgãos da fé pública, S. Paulo, 1897, p. 10 e segs.

(19) SAuER, Grandlagen des Prozessrechts, Stuttgart, 1919, p. 235 e seg. 
a ciência e nelas há de viver todo homem, pois só assim pode atuar eficazmente em favor da cultura. A monada de valor é a menor unidade, que a ciência procura compreender. Mediante a agrupação das monadas de valor se integra o todo, a cujo conhecimento se destina a Filosofia. (20)

16 - Encarando o processo sob o ponto de vista da monada de valor, SAuer, dá uma explicação inteiramente nova: “As monadas de valor do Direito Processual vivo porfiam por realizar a lei fundamental, com- o objetivo de criar segurança jurídica, estruturando em concreto o direito objetivo e assegurando o império da justiça. É de desejar que esta concepção do Direito Processual e sua atuação prática satisfaçam as necessidades de todos os interessados e redundem em benefício do próprio Estado." (21) $\mathrm{Na}$ mais recente de suas obras, SAuer retoma essas idéias e diz: "O principal é atingir o resultado satisfatório num caso particular com uma teoria (é evidente que também incontestável sob o ponto de vista lógico e jurídico positivo), a saber, um resultado que corresponda às necessidades jurídicas, ao bem público, à consciência popular em consonância com a justiça. Esse é o objetivo para o qual deve tender desde o comêço, sem que o julgador tenha a liberdade de se perder em lifigranas lógicas. Por isso é que devem ser postas a descoberto as monadas jurídicas e patenteado o seu vínculo harmônico."

17 - JoÃo Mendes JúnIor fêz, por seu turno, uma aplicação da filosofia aristotélico-tomista à ciência do processo. Os princípios fundamentais podem ser assim compendiados: a) - aplicação da teoria do movimento no processo

(20) SAUER, Filosofia Jurídica y social, Ed. Labor, 1935, p. 77.

(21) SAUER, op. cit. p. 272.

(22) SAuER, Allgemeine Prozessrechtslehre, 1951, p. 28, nota 9. 
civil; (23) b) — distinção entre substância e acidente na doutrina das ações; (24) c) - renovação do conceito de instância; (25) Relativamente à aplicação ao processo da teoria do movimento, escreveu: "Tôda atividade realiza-se pelo movimento, que é sempre o resultado do concurso das fôrças físicas, postas à disposição de uma causa inteligente ou princípio superior e ordenado por êste princípio para um fim. O direito, como tudo quanto existe na natureza, não se realiza senão pelo movimento; o movimento não se realiza senão no fato individuado, seja mediante um só ato, seja mediante atos e têrmos, continuados e sucessivos, ordenados para um fim. Os atos, contratos e sentenças não têm por objeto imediato o direito em tese, nem mesmo o direito em hipótese, mas o direito em causa, isto é, um fato individuado pelas circunstâncias na quantidade $e$ determinado pela lei na qualidade. Este fato, assim individuado e qualificado, é causa material ou móvel no movimento da instância, quer pela celebração dos negócios (atos e contratos), quer para o litígio em juízo (demandas ou pleitos). A linguagem vulgar exprime perfeitamente estas idéias: negotium, id est, tractatum ultro citroque habitum; quando surge litígio, as partes dizem que "estão movendo uma causa em juizo" (26)

18 - O processo é, para João Mendes Júnior, o movimento da ação em juízo, isto é, o curso de "atos" e "têrmos" da ação na "ordem" do juízo. Ordem é a disposição dos meios em relação ao fim. Os atos do processo são "meios", que devem ser dispostos em "ordem", tais e tantos quais e quantos sejam necessários para chegar ao fim da ação.

(23) Cf. JoÃo Mendes Júnion, A reformação do nosso processo (Revista do Supremo T'ribunal, vol. 26, p. 262).

(24) João Mendes Júnion, Direito Judiciário Brasileiro, 2. ${ }^{\mathrm{a}}$ ed. p. 101 e 255;

(25) João Mendes JúnIon, Direito Judiciário Brasileiro, p. 441.

(26) JoÃo Mendes JÚNIOR, Direito Judiciário Brasileiro, p. 16 e segs. 
Os "têrmos" do processo assinalam o princípio e o fim de cada movimento no espaço e no tempo; no processo forense, assim como em tôda ação constituída por movimentos parciais, formando um movimento continuado e sucessivo, os têrmos são fixados pelo tempo, como número e medida de duração e sucessão dos atos; por conseguinte, os têrmos da duração devem ser normalmente proporcionados aos "atos praticados" de sorte que não sejam nem supérfluos, nem insuficientes. $O$ movimento é proporcional não só à intensidade ou ao pêso do móvel, como à duração e sucessão no tempo. O movimento é tanto mais veloz quanto mais breve é o tempo em que se consuma, e tanto mais longo quanto mais longo é o tempo, de sorte que quanto mais complicados são os atos processuais, mais lento e vagaroso é o movimento e proporcionalmente mais longo o tempo para produzí-los na instância. (27)

19 - Para fixar o conceito de ação, parte João Mendes JÚNIOR da conhecida distinção entre substância e acidente. A lei, como preceito comum, é uma substância; e, como tal, é afetada por outros predicamentos ontológicos, isto é, pelos nove acidentes. A lei, pois, como um ente substancial, tem qualidade, quantidade, relação, e se realiza no tempo, no lugar, em situação, com hábito e mediante ação e paixão; isto é, age sôbre o mundo externo e sofre a ação do mundo externo. A ação é o acidente, mediante o qual a substância produz efeito: "actio est accidens, quo mediante, substantia producit effectum. E', por isso, o Código Civil, no art. 75, determina que - "A todo o direito corresponde uma ação que o assegura." Agir, dizemos geralmente tudo aquilo que produz alguma mutação, ou tudo quanto faz que uma coisa seja o que antes não era; agir, na linguagem do direito, é fazer alguma coisa que produz um efeito jurídico; neste sentido o têrmo complexo - ação

(27) João Mendes JúnIoR, A reformação do nosso processo, (Revista do Supremo Tribunal Federal, vol. 26, p. 262). 
da lei - foi empregado em diversos textos do Direito Romano, pôsto que depois fôsse particularmente aplicado à ação judiciária (MAINZ, Dir. Rom. I, § 119, notas 8 e 9; Jhering, Esp. do Dir. Rom. IV, \& 63). A lei jurídica age sôbre as pessoas obrigadas, atingindo-as ou por um contacto virtual, ou por um contacto físico. Age por um contacto virtual, quando é voluntàriamente cumprida; reage por um contacto físico, quando se impõe pela intervenção ou pela fôrça do poder público. As vontades individuais, criando, respeitando ou extinguindo direitos na conformidade da lei, praticam - ato jurídico; mas, quando violam, desconhecem ou ameaçam direitos individuais, a lei, na ordem social, sòmente pode reagir pela fôrça do poder público, mediante a ação judiciária, em que se manifesta a ação do autor, declarando a sua intenção, contenção e remissão, assim como a reação do réu, declarando a sua contrariedade, contenção e remissão, e o conhecimento do juiz, para o final julgamento e execução. Agere et pati recipiunt contrarietatem et contestationem ac remissionem (ARISTOT. Praedicam, cap. V e VI, de actione et passione). Estas noções ontológicas encontram realização na ação judiciária, que na doutrina, na legislação e na jurisprudência, é considerada em quatro sentidos ou acepções: na acepção subjetiva, na acepção objetiva, na acepção material e na acepção formal." (28). No sentido subjetivo, a ação é um direito; no sentido objetivo, a ação é um remédio de direito; no sentido material, a ação é uma lide ou litígio; e no sentido formal, a ação é um processo de atos.

20 - Dentro de uma concepção rigorosamente unitária, aplicou JoÃo MENDES JúnIOR os princípios filosóficos à teoria da instância. "Instância", escreveu, "é a existência fluente do mesmo móvel, isto é, a identidade do móvel, antes e depois, no curso do movimento. Instancia est existentia fluens, id est, identitas mobilis aut quaedam unitas ducta

(28) JoÃo Mendes JúnIoR, Direito Judiciário Brasileiro, p. 101 e 102 . 
in numerum prioris et posterioris (ARISTóteles, Physica, liv. IV, cap. 14, n. 2). O móvel em juizo é a causa, isto é, a relação litigiosa; e, assim, - instância, no fôro, é a existência fluente do litígio, isto é, a identidade da causa, ou relação litigiosa, antes e depois, tal como ficou fixada na contestação da lide. A existência é a atualidade real da coisa; relativamente ao litígio em juízo, esta atualidade consiste em expor a causa e provar os fatos perante o juízo. A fluência consiste na continuidade do tempo correlativamente à continuidade do movimento do mesmo móvel. o tempo é um contínuo-sucessivo; e esta continuidade-sucessiva do tempo chama-se fluência, porque o passado já se foi, o futuro ainda será, e o presente flui, unindo ao futuro o curso do passado... A existência fluente do litígio em Juízo, como diziam os romanos, se realiza pela postulação, pela dilação e pela judicatura: postulatio, dilatio, judicatio. São essas as três manifestações da instância." (29)

21 - Expusemos, em apertada síntese, as duas doutrinas filosóficas do processo. A primeira, elaborada por SAUER na Alemanha, não prosperou. Vive tão sòmente no pensamento do filósofo e processualista de Koenigsberg. A filosofia do processo de João Mendes Júnion teve, ao contrário, fortuna singular no Brasil. As suas idéias lograram acolhimento na obra de notáveis processualistas, sendo adotadas mesmo por aquêles que se não filiam à concepção filosófica aristotélico-tomista. $O$ eminente Prof. Benedito de Siqueira Ferreira, na monografia de concurso, em que se sagrou catedrático de Direito Judiciário Civil nesta Casa, perfilha parcialmente o conceito de ação formulado por Joño Mendes Júnior. S. Exa. parte de um famoso passo de JoÃo Mendes Júnior, que sustenta que "a ação é sempre um movimento e todo movimento tende para um fim; todo movimento tendente a um fim imediato consiste em um só ato; mas quando êsse fim não pode ser conseguido imediatamente, o movimento é continuado por atos intermédios, que

(29) JoÃo Mendes JúnIon, Direito Judiciário Brasileiro, p. 441. 
para realizar a tendência e dirigir-se para o fim intentado, devem seguir para diante coordenadamente, uns causando os outros." (30) E acrescenta o Prof. Siqueira Ferreira - : "E, na realidade, é isso que ocorre na ação judiciária: tendendo a mesma ao exercício da atividade jurisdicional do Estado, como êste não pode ser um fim imediato, a ação comporta uma série de atos ordenados, que vão metamorfoseando a relação processual que outra coisa não é senão o próprio direito de ação objetivado, em relação ao qual os atos processuais são outras tantas facultates exigendi." (31) E mais adiante afirma: "Na acepção material, como JoÃo Mendes, ação como litígio em juízo acêrca de uma relação de direito. Finalmente, identificando ação e relação processual, podemos aceitar de JoÃo Mendes a definição da ação em sua acepção formal, modificando-se ligeiramente e dizendo que a ação, em sua acepção formal, nada mais é que a série ordenada e processual dos atos formalizados pela lei e mediante os quais se estabelece e se desenvolve a relação processual." (32)

22 - Outro eminente processualista, em cuja obra se refletem as idéias filosóficas do Mestre, é o Prof. LOPES DA Costa. No seu Tratado de "Direito Processual Civil Brasileiro", que se desenvolve em quatro volumes, consagra e aplica os fundamentos da filosofia aristotélico-tomista. Logo ao abrir o volume primeiro, diz: “os atos humanos voluntários perseguem um fim, que a todos êles inspira e sôbre todos impera, pois conforme a conhecida observação de S. Tomás de Aquino, na ordem da razão prática o "fim" é "princípio" na ordem da razão teórica. Os que se praticam em juízo, para proteção do direito, visam um ato do poder jurisdicional (decisão, execução, medida cautelar), têm a mesma finalidade, são interdependentes, se-

(30) João Mendes JúnIoR, Direito Judiciário Brasileiro, p. 257 e seg.

(31) Benedito de Stquetra Ferreira, Da natureza jurídica da ação, S. Paulo, 1940, p. 230.

(32) Benedito de Siqueira Ferreira,, op. cit. p. 242 e seg. 
riados, integrando assim um processo". (33) 0 processo é assim um conjunto de atos, que formam um todo. Por sua vez, "o ato é todo movimento do ser vivo, quer se exteriorize, influindo sôbre outro ser (actio quae in exteriorem materiam transitQ, quer permaneça no íntimo do agente (actio quae in agente manet - S. Tomás, Suma, I, p. 18, ad 1). Os atos mais importantes são declarações de vontade." (34) Aceita LOPES DA Costa também a lição tomista (35), segundo a qual "há no movimento quatro causas: causa final, que leva o motor a mover; o motor, que é móvel e que é a causa motriz ou causa eficiente; o móvel, que é movido, e o têrmo, ao qual chega afinal o movimento ou o que o móvel adquire e recebe sob a ação do motor (PÈGués, Initiation thomistique, 118). Em vários outros tópicos de sua obra, o douto professor de Minas reafirma a sua convicção tomista, ora dizendo que "o que dá existência à sociedade é a ordem", pois, "o legislador humano imita o legislador divino, de quem recebeu a inteligência e o poder"; (36) ora dizendo que "o homem é um composto de matéria e espírito, corpo e alma"; a sociedade é assim um todo; "procura então o bem comum"; (37) ora concluindo (38) que "é o bem comum a causa final da lei. Vendo-se a lei, superficialmente, podemos não percebê-lo. A razão está naquêle princípio tomístico: quod primum est in causando ultimum est in causato. "A noção de fim pressupõe a de causa eficiente e a de causa formal". $\mathrm{Na}$ ordem da causalidade, encontramos primeiro o bem, que é o fim, e que põe em ação a causa eficiente. Esta move

(33) Lopes DA Costa, Direito processual civil brasileiro, vol. I, n. 1 , p. 4.

(34) Lopes da Costa, op. cit. I, n. 236, p. 311.

(35) LoPES DA Costa, op. cit. II, n. 126, p. 136; e ainda, vol. II, n. ${ }^{\circ} 168$, p. 173.

(36) Lopes dA Costa, op. cit. I, n. ${ }^{\circ} 4$, p. 7.

(37) Lopes dA Costa, op. cit. I, n. ${ }^{\circ} 40$, p. 53 e 54.

(38) Lopes dA Costa, op. cit. III, n. ${ }^{\circ} 4$, p. 5. 
à nova forma, que, finalmente, realiza o efeito." (S. Tomás, Suma Teol. I, 2.5, a. 4)"

23 - Mas dentre os discípulos do Mestre, nenhum foi mais fiel ao seu pensamento do que o Desembargador Manuel Carlos de Figueiredo Ferraz. Em sua obra "Apontamentos sobre a noção ontológica do processo", de cunho nitidamente filosófico, o eminente autor proclama a sua adesão à doutrina aristotélico-tomista do movimento, que, considerado do ponto de vista ontológico, é o ato de um sujeito formalmente em potência; (39) aceita a noção dualista de substância e forma, potência e ato, que nascem da análise do movimento, (40) o qual pode ser definido "a passagem do movimento ao ato"; (41) e desenvolve a teoria das causas do movimento forense, que são, a saber: a) - a causa eficiente, - juizes, auxiliares da justiça, partes contratantes ou litigantes; b) _ a causa material, os fatos, que constituem os títulos de direito ou relações litigiosas; c) - a causa formal, os atos e têrmos do processo, quer para declarações de vontade ou estipulações no fôro extra-judicial, quer pela intenção, ou contestação, prova, julgamento e execução no fôro judicial; d) - e a causa final, isto é, no fòro extra-judicial, a estipulação ou firmeza, e, no fôro judicial, o julgamento e a execução do julgado; (42) estuda finalmente a natureza da lei processual, num capítulo rico de observações, onde a par da aplicação rigorosa dos princípios, ajunta a sua crítica pessoal, banhada e transfigurada pela devoção quase mística que tinha para com o sábio e santo Mestre. (43)

(39) Manuel Carlos, Apontamentos sôbre a noção ontológica do processo, S. Paulo, 1936, p. 33.

(40) Manuel Carlos, op. cit. p. 29.

(41) Manuel Carlos, op. cit. j. 71.

(42) Manuel Carlos, op. cit. p. 88 e seg.

(43) Manuel Carlos, op. cit. p. 113 e segs. No "prefácio" escreveu: "Era êle o verdadeiro tipo de sábio. Assim o qualificou o eminente cientista frances G. DuMAS, após travar conhecimento com 
24 - Entre os professôres desta Casa, aquêle em cuja obra reluz com mais freqüência o pensamento do Mestre, é o eminente Prof. Gabriel de Rezende Filho, de quem fui discípulo e com quem continuo sempre a aprender. Em seu "Curso de Direito Processual Civil", lembra, a propósito dos têmas fundamentaịs, a lição de JoÃo Mendes Júnior, relativamente aos órgãos da fé pública, (41) à classificação dos atos processuais, (45) ao caráter da citação (46), ao conceito de prova, (47) aos elementos integrativos da escritura pública (48) e à definição de confissão; (49) porèm a mais importante citação se refere ao conceito de ação. Diz: "Joño Mendes (obra cit. pag. 96), porém, valendo-se dos princípios da Escolástica, vale dizer, das quatro causas aristotélicas, define a ação sob os aspectos subjetivo, objetivo, material e formal. Na acepção subjetiva, a ação, considerada quanto à sua causa eficiente, é um atributo do sujeito, isto é, um direito do autor. E direito de requerer em juízo aquilo que nos é devido: jus persequendi in judicio quod sibi debetur, como define Cesso. $\mathrm{Na}$ acepção objetiva, a ação, considerada quanto à sua causa final, é um meio ou remédio de direito para pedir ao juiz que obrigue a outrem a dar ou fazer aquilo de que tem obrigação perfeita, segundo a define Correia Teles. $\mathrm{Na}$ acepção material, a ação considerada quanto à sua causa material, é o litígio em juízo acêrca de uma relação

êle num encontro fortúito. Rosto de asceta, olhar profundo, fronte calçada de meditação. No todo, uma figura de santo, desde a modéstia quase desalinhada do traje até a humildade digna do porte." (op. cit. p. 14 e seg.).

(44) Gabriel de Rezende Filho, Curso de Direito Processual Civil, I, n.o 48.

(45) Gabriel de Rezende Filho, op. cit. II, n. 350.

(46) Gabriel de ReZende Filho, op. cit. II, n.` 448.

(47) Gabriel de Rezende Filho, op. cit. II, n. 620.

(48) Gabriel de Rezende Filho, op. cit. II, n. 708.

(49) Gabriel de Rezende Filho, op. cit. II, n.o 724. 
de direito. E pleito, a demanda. Finalmente, na acepção formal, a ação, quanto à sua causa formal, é o processo." (50)

A invocação das obras dos professôres Gabriel DE Rezende Filho, Siqueira Ferreira e Lopes da Costa e do Des. Manuel Carlos, indica quão profunda foi a influência do pensamento de JoÃo Mendes JúnIor na construção filosófica do Direito Judiciário Brasileiro. A originalidade da concepção lhe permitiu criar uma doutrina do processo e da ação, iluminada pelos princípios filosóficos, que constituiam a base de sua formação intelectual. (51)

\section{V - o caráter da obra}

25 - O tratado contínuo com as obras dos clássicos latinos permitiu a JoÃo MENdes JúnIOR vasar o pensamento jurídico, em vernáculo, com rigor geométrico. Creio não exagerar, dizendo que JoÃo MENDES JúnIOR raciocinava em latim e escrevia em português. $O$ seu estilo se assemelha muito ao de CHovenda; a linguagem dêste Mestre é austera, desataviada, pouco maleável, sem vivacidade. Mas à medida que aprofundamos o seu pensamento, percebemos que êle é na Itália o maior de todos, porque ninguém o iguala na exatidão dos conceitos, na paciência beneditina da investigação histórica e na simetria do conjunto rigoro-

(50) Gabriel de Rezende Filho, op. cit. I, n.o 153; ver aindid vol. II, n.o 349: “A ação, em sua acepção formal, é a série ordenada e processual de atos formalizados pela lei para o litígio em juízo sôbre uma cau.sa ou relação de direito."

(51) Merece ainda ser Iembrada a obra de Galdino de Siquerra. Prática Forense, editada em S. Paulo, em 1907, que expõe fielmente as lições de JoÃo Mendes Júnror, professadas na Faculdade de Direito; e o estudo de Esther de Figueiredo Ferraz, A orientação

filośfica de João Mendes Júnior, publicada em "Ensáios de Fiīosofia do Direito", ed. Saraiva, 1952, p. 48 e seg.s. 
samente harmônico. Seus períodos não têm uma palavra a mais; também não podem ter uma palavra a menos. João Mendes Júnior escrevia do mesmo modo. $O$ Direito Judiciário Brasileiro se assemelha às Instituições de CHIOvENDA. Estas obras não têm citações, recheadas de autores e indicativas de erudição. O pensamento é condensado no mais alto grau; cada capítulo pode desdobrar-se em uma monografia; e em cada linha floresce uma idéia. Permití-me que, a título de exemplo, destaque do conjunto um instituto para dar uma idéia de como trabalhava o nosso Mestre. Tomemos os embargos do executado. O estudo sôbre a natureza dos embargos, ao tempo em que escreveu JoÃo Mendes Júnior, foi posto à margem e considerado um dos mais complicados do processo, não só por falta de uma sistematização científica, como também pelas dificuldades em se definirem os princípios sob um ponto de vista geral e teórico. (52) Não se cuidou de saber qual a sua natureza jurídica, se de uma defesa em sentido técnico, se de uma ação do embargante contra a execução aparelhada. Ora, diz João Mendes Júnion (53) que "com os embargos do executado se manifesta na execução uma nova instância." Eis aí uma linha apenas, que contém um enunciado fundamental. (54) A abertura de instância só ocorre mediante propositura de ação. Os embargos do executado constituem, portanto, ação do executado contra a execução forçada. Nada mais exato. (55)

26 - Ainda sob o mesmo feitio das proposições sintéticas, formula JoÃo Mendes JúnIOR o conceito de processo

(52) Paula Batista, Processo Civil, § 207; Leite Velho, Execuções, p. 239; JoÃo Monteiro, Curso de Processo, p. 813; Afonso Fraga, Execuções, p. 263; Costa Carvalho, Execuções, p. 146-147.

(53) João MENDES JúnIor, Direito Judiciário Brasileiro, p. 550.

(54) Cf. Alfredo Buzaid, Do Agravo de Petição, 2. a ed. p. 110; nota 36 .

(55) Lopes da Costa, Direito Processual Civil, II, p. 138. 
como "segurança constitucional dos direitos". (56) São suas palavras: "Estes atos do processo, tais como a citação, a proposição da ação, a contestação, a réplica, a tréplica, a produção das provas, as alegações, a sentença, os recursos, cada um dêles deve ser considerado meio, não só para chegar ao fim próximo, que é o julgamento, como ao fim remoto, que é a segurança constitucional dos direitos." (57) Ao tempo em que essa linha fôra escrita, o conceito de processo ainda não tinha sido elevado, no Brasil, à eminência de garantia constitucional de direitos. O feliz enunciado, que integra o processo no domínio do direito público, brilhou, no entanto, como um clarão de alvorada. A idéia de um Direito Processual Constitucional floresceu depois, entre nós, na obra do eminente professor e magistrado, José Frederico Marques e, no Uruguai, em famoso estudo escrito pelo inesquecível Mestre Eduardo Couture. (58)

Êstes dois exemplos mostram como trabalhava João Mendes Júnior. Para surpreender as jóias, que recamam tôda a sua obra, é preciso lê-lo vagarosa e pacientemente. o merecimento dos seus continuadores consiste em separar, na sua contribuição científica, o que é imortal, do que é perecível.

\section{VI - 0 ministro do supremo tribunal.}

27 - Quando em princípio de 1917 JoÃo Mendes Júnıor assume o lugar de Ministro do Supremo Tribunal Federal,

(56) Jõ̃o Mendes Júnion, Revista da Faculdade de Direito de S. Paulo, vol. VII, p. 120.

(57) JoÃo Mendes Júnior, A nova fase da doutrina e das leis do processo brasileiro, (Revista da Faculdade de Direito, vol. VII, p. 120).

(58) JosÉ Frederico MARques, Ensaio sôbre a jurisdição voluntária, S. Paulo, 1952, p. 13; EduARDo Couture, Las garantias constitucionales del proceso civil (Estudios en honor de Hugo Alsina, p. 153 e segs.). 
já não eram satisfatórias as suas condições de saúde. Lá permaneceu por mais de um lustro. Os acórdãos ou votos, que redigia, eram geralmente curtos; continham o essencial. (59) Sua preocupação era exprimir com clareza o julgamento do Tribunal. Só mui raramente é que ilustrava o acórdão com a lição dos doutores, selecionados com rigor e transcrita com tôda oportunidade. Era, porém, nas discussões em plenário que revelava o esplendor de sua vasta cultura e invejável erudição. (60) A Revisão do Supremo nos dá notícia dos memoráveis debates travados com os seus pares, especialmente com Pedro Lessa. João Mendes JúNIOR era o argumentador, lógico e frio; conhecendo profundamente a história, o direito e a filosofia, invocava a cada passo os textos romanos, aplicáveis aos casos concretos; a doutrina dos antigos juristas portuguêses lhe era tão familiar como o último estado da ciência jurídica dos povos civilizados; não procurava impor sua opinião; mas porfiava na defesa da boa doutrina. Seus votos tinham a serenidade de um raio de sol. Quando discrepava do sentir da maioria, limitava-se a assinar vencido. Pedro Lessa era em tudo diferente. Os acórdãos, que redigia em longas páginas, revelava o polemista vigoroso e o brilho de seu talento, alicerçado em eruditas e abundantes citações de autores estrangeiros e nacionais. Quando era vencido na votação, escrevia o voto divergente, combatendo, com largueza de vistas e firmeza de convicção, a tese adotada pela maioria de ministros. Sua alma vibrante e do-

(59) Cf. Revista do Supremo Tribunal, vol. XIII, p. 42 e 382; $\mathrm{XV}$, p. 259; XVI, p. 46; XVII, p. 43; XX, p. 28, 59, 61, 62, 65 e 78; XXI, p. 29, 254, 281, 298 e 461; XXIII, p. 121, 142 e 219; XXIV, p. 283; XXV, p. 152 e 251.

(60) Cf. Revista do Supremo Tribunal; vol. XIII, p .435 e seg.; XIV, p. 463 e 477; XV, p. 78, 535 e 558; XVII, p. 83, 110, 279, 290, 294 e 311; XVIII, p. 338 e 345; XIX, p. 397, 406, 414, 605 e 609; XXI, p. 119, 535 e 565; XXIII, p. 57 e 172; p. 103. 
minadora sacudia com freqüência o Supremo Tribunal, lutando para que prevalecesse o seu julgamento.

\section{VII - Conclusão}

28 - Aí estão bosquejados, em largos traços, alguns aspectos da vida e da obra do Mestre, cujo centenário celebramos. Dentre tôdas as atividades intelectuais de seu iluminado espírito, aquela que correspondeu à sua vocação íntima foi o exercício do magistério. A disciplina, que ensinou nesta Casa, é uma ciência de finalidade eminentemente prática. Mas, como observou Jhering, "a ciência precisa, para ser verdadeiramente prática, não se limitar ao prático. (61) João Mendes JúnIor subiu à definição dos princípios, porque "o conhecimento das coisas não se completa sem o conhecimento das causas." (62) Mas depois, observa o eminente prof. Luís Eulálio de Bueno Vidigal, "desce o Mestre ao campo raso do processo, e, então, o polemista mostra, em tôda a sua pujança, o quanto pode o jurista ganhar quando alia ao conhecimento das leis o hábito da investigação filosófica. (63) João Mendes JÚNIOR trouxe uma contribuição, verdadeiramente original, para o estudo dos conceitos de ação, processo e instância. A característica da originalidade não está tanto em fazer tábua rasa de tudo que a ciência investigou outrora e foi incorporado ao patrimônio intelectual da humanidade, quanto na formulação diferente $e$ nova de conceitos, relativos ao mesmo fenômeno jurídico, encarado já agora sob outro ângulo visual. $O$ progresso científico se realiza mediante

(61) R. Von JHering, Iahrbuecher fuer die Dogmatik, I, 18; Cf. Pontes de Miranda, Tratado de Direito Privado, I, Prefácio, p. XXIII.

(62) JoÃo Mendes JúnIor, Elementos de lógica e psicologia, p. 187.

(63) LuIZ E. DE BuENo VIdigAL, Os Mestres do Direito Judiciário Civil na Faculdade de Direito de S. Paülo, vol. XIX, p. 341). 
um aperfeiçoamento per gradus, que parte das idéias existentes para as arrojadas e benéficas revisões do pensamento. As doutrinas não surgem por acaso, nem são criações, puramente acadêmicas, engenhadas no silêncio dos gabinetes de trabalho, ao sabor do desejo de dizer coisas diferentes; elas traduzem o sentir de um momento histórico numa evolução gradual, que se prende ao passado para se projetar no futuro. Utilizando idéias da filosofia aristotélico-tomista e aplicando-as à ciência do processo, êle foi autêntico criador de uma doutrina, que logo fêz discípulos e teve continuadores. Podemos divergir de sua sistemática e criticar-lhe as idéias filosóficas, mas todos devemos reconhecer que êle foi o processualista, que concebeu, traçou e expôs uma doutrina brasileira do Direito Judiciário. Éste merecimento envolve a sua obra com a auréola de glória. É porisso que todos proclamam que o homem viveu como um santo; o professor ensinou como um sábio; e o magistrado decidiu como um justo. 